\title{
THE POSITION AND AUTHORIZATIONS OF ENFORCEMENT OFFICERS IN THE BELARUSIAN LEGAL SYSTEM
}

\begin{abstract}
Considering the fact that the profession of the enforcement officer has an increasingly efficient role both in securing and realizing creditors' claims, which was significantly contributed by the introduction of the system of the enforcement officers as independent, non-state entities in a large number of legal systems (the so-called out of the court enforcement officers), the author analyzes the Belarusian model according to which the profession of the enforcement officer is still a part of the apparatus of the state power and its basic features. In some places, the author will make a comparison with the current position of enforcement officers in Republic of Serbia, and present a conclusion on the efficiency of both models.
\end{abstract}

Keywords: enforcement, the administration of the forced execution, enforcement officer, bailiff, authorization, duty

\section{Introduction}

The role of the state is to decide, through its bodies, on legal request of the enforcement creditor contained in the motion for enforcement, and if all the procedural and material preconditions for passing the enforcement writ have been met, to take particular actions in order to enforce creditor's claim. The state conducts its role through the courts, but also through persons who are entrusted with authorizations in the enforcement proceedings. ${ }^{1}$

\footnotetext{
* Ph.D., The Vicepresident of the Chamber of public enforcement officers of Republic of Serbia, e-mail: nsizvrsitelj@gmail.com

${ }^{1}$ Bodiroga, N. (2017). Novi izvršni postupak [New Enforcement Proceedings]. Beograd, Pravni fakultet Univerziteta u Beogradu, p. 16.
} 
The Republic of Belarus always has had a state system of enforcement. After gaining independence, the Soviet system of enforcement still existed, in which the enforcement officers were present in the courts. As a result of the reform of justice carried out in 2013, the enforcement entities were derived from the courts, forming a separate system, under the supervision of the Ministry of Justice of the Republic of Belarus. ${ }^{2}$

\section{The position of enforcement officers, manner of work and terms of appointment}

The authorizations for enforcement of court judgments and other enforceable documents in Belarus are conducted by court enforcement officers and public enforcement officers (managers, experts). ${ }^{3}$ Therefore, in the Republic of Belarus, there are no private enforcement officers. The enforcement officers, or in the original term public bailiffs, ${ }^{4}$ are persons who are directly appointed for enforcement of court judgments and other enforceable documents, based on the official authorizations. While conducting their duties public enforcement officers are representatives of the state power and are under the protection of the state.

In terms of appointment, the enforcement officer has to be the citizen of the Republic of Belarus who speaks state languages of the Republic of Belarus, has high school special or university degree or is educated at the institution that confers university education, is capable of conducting duties coffered upon him/her based on his/her professional knowledge, moral and business qualities. In certain circumstances, the citizen of the Republic of Belarus with different university education in terms of major, which is defined by the Ministry of Justice of the Republic of Belarus, may be appointed for

\footnotetext{
${ }^{2}$ The enforcement proceedings in Belarus are regulated in accordance with the Law of the Republic of Belarus dated October 24, 2016 no. 439-3 „On the Enforcement Proceedings“ (The National Legal Internet Portal of the Republic of Belarus dated November 15, 2016, 2/2437.), as well as Guidelines to the Enforcement Proceedings developed based on it and approved by the resolution of the Ministry of Justice of the Republic of Belarus dated April 7, 2017 no. 67.

${ }^{3}$ In accordance with Article 1 of the Law of Republic of Belarus dated October 24, 2016 no.440-3 „On court enforcement officers“.

${ }^{4}$ Bailiff was a medieval term recognized in the Law of the emperor Dusan and implied the permanent body of the Serbian Medieval Court who was entrusted with public trust, i.e. a person who confirmed the facts established by the judge and took care that such a decision was fully enforced. Selaković, N. (2007). Dušanov zakonik i pravni transplanti [Dusan's Law and Legal Transplants]. Beograd, Pravni fakultet Univerziteta u Beogradu, p. 80.
} 
the enforcement officer (currently such majors include economy and political science).

The appointment includes a test on the law on enforcement proceedings, and for the persons who are admitted for the first time to the state service, the qualification exam is a precondition in the manner prescribed by the president of the Republic of Belarus. However, preliminary testing will evaluate a citizen who is admitted to the state service in the period from three to six months and if the results are unsatisfactory the state officer will be discharged from the service.

Furthermore, in terms of organization of enforcement service, the system of enforcement in Belarus consists of different level authorities. The main enforcement administration of the Ministry of Justice is managing the system of enforcement authorities, while the lower instance authorities have a hierarchy and are organized in accordance with the territorial principle - enforcement administration of main administration for justice of regional (city of Minsk) executive boards ( 7 in total), districts (semi district), city and city enforcement administrations (142 in total).

Each of these bodies has their own manager on top. The manager of the Main Enforcement Administration of the Ministry of Justice is the principal public enforcement officer of the Republic of Belarus, who is appointed and discharged by the minister of justice. Furthermore, the managers of enforcement administrations of the principle enforcement administration of justice of regional (city of Minsk) executive boards, who are the principle enforcement officers in the regions (city of Minsk) are appointed and discharged by the minister of justice in cooperation with regional (city of Minsk) executive boards. Finally, the managers of a district (semi-district), city, districts in city enforcement departments are appointed and discharged by the managers of the district (city of Minsk) executive committees. Finally, other enforcement officers and employees in enforcement administrations and enforcement departments are appointed and discharged by managers of these administrations.

Based on that we may conclude that the main characteristic of the status of enforcement officers in Belarus legal system is that they act in the role of representatives of state power and that they have official authorizations while carrying their professional duties. On the other hand, since in the Republic of Serbia appointed public enforcement officers are acting in the capacity of nonstate entities entrusted with public authorizations, a specific comparison may be made between official authorizations and public authorizations at stake. However, the inevitable differences between the scope of authorizations of the state and non-state entities will be analyzed in the next part of this paper. 
In terms of appointment of persons who perform the service in the enforcement authorities of Belarus, we may notice certain similarities with the domestic legal system and the role of competent Ministry in this system. However, although there is no hierarchy in the structure of the enforcement authorities, and thus there is no influence of the members of the higher instance bodies on the appointment of the members of lower instance bodies, one may notice a similarity in the appointment of the highest representatives of the Belarus enforcement service. Furthermore, the term enforcement administration implies something which is typical for state administration that is characterized by a hierarchic constitution and authoritative approach, unlike independent professional officers vested with public authorizations appointed directly by the competent minister, which exist in our country. In addition to that, professional enforcement officers' associations are not present in the Belarus legal system.

\section{Authorizations and duties of enforcement officers}

\subsection{The review of the most important authorizations of the enforcement officer}

The authorizations of the enforcement officers as state as well as nonstate entities may be divided into several groups. They first include the authorizations that are related to the identification of enforcement debtor's property, which in terms of chronology precede enforcement activities, approving enforcement, conducting enforcement, mediation between the parties and participants in the proceedings. ${ }^{5}$

If we pay attention to authorizations that are aimed to identify participants in the enforcement proceedings and property of enforcement debtor, we will find many of them in the legal system of Belarus. At the time of processing the data on the participants of enforcement proceedings, the enforcement officers are authorized to check documents that prove the identity of participants in the proceedings and that confirm the authorizations of their representatives. Furthermore, the enforcement officer can obtain, without written consent of an individual, information from resources and databases that contain personal data on participants in the proceedings, including the use of

\footnotetext{
${ }^{5}$ Bodiroga, N., op. cit., pp. 115-118.
} 
national automated information systems. ${ }^{6}$ In addition to that, in cases set forth by the law enforcement officers are authorized to call a search for enforcement debtor with the assistance of the police and to pass a decision to take into custody the debtor as a natural person, a representative of the debtor as a legal entity or owner of the property (founder, member) of a debtor which is a legal entity. Finally, the enforcement officer is authorized to file charges to the competent authorities to decide on deportation from the Republic of Belarus of foreign citizens and persons without citizenship who are the debtors in the enforcement proceedings.

In terms of access to the property of the enforcement debtor, the enforcement officer is authorized to enter the land, apartments, non-residential premises of the enforcement debtor and to freely enter the territory and premises of entrepreneurs and legal entities and to promptly meet the managers and other officers of a legal entity. In addition to that, if there is a need for that, an enforcement officer may enter by force to such premises and search them. However, if a debtor or other person does not allow the enforcement officer to access the land parcel, residential, non-residential areas in which the debtor's property is located, the enforcement officer will access these premises based on the decision of the court. In accordance with this, the enforcement officer is authorized to inspect the furniture, safe deposit boxes and other possible places for property keeping, including money, valuable assets and documentation used by the debtor in order to identify debtor's property that may be the subject matter of enforcement in the enforcement proceedings.

We may notice that certain authorizations, and especially those related to the participation of enforcement officers in announcing a search, taking into custody of enforcement debtor and deportation of enforcement debtor from the country are the most evident exceptions comparing to the authorizations of a public enforcement officer in the Republic of Serbia. In the domestic enforcement proceedings, the above stated authorizations were not part of the enforcement officer's competence even at the time when enforcement was exclusively in the competence of the state, i.e. court system (i.e. they were

\footnotetext{
${ }^{6}$ In such a manner, the data on the passport, place of residence, employment of enforcement debtor, bank accounts of legal entities and entrepreneurs, data on mobile operator, internet services used by enforcement debtor, registered motor vehicles and other registered property of enforcement debtor as well as issued hunting permits are available to enforcement officers. The enforcement officers also have the insight into the data base of National bank, custom and border authorities. Avdeev, A. (2015). The sufficiency of the restriction measures against debtors in the process of enforcement proceedings, The Restriction of the Rights of the Debtor: The Latest Legislative Changes and their Implementation, 6th International Scientific and Practical Conference, 8-10 September 2015, UlanUde, Republic of Buryatia, p. 219.
} 
recognized only in the criminal proceedings). Therefore, their presence in the Belarus enforcement proceedings reflects in the best way the state structure of this service and broad scope of authorizations against the enforcement debtor, which includes also the use of force. In addition to that, the broader scope of enforcement's authorizations comparing to the domestic system is obvious in the access to movable and immovable property of the enforcement debtor, for which the enforcement officer does not need the assistance of the police, even in case of enforcement debtor's resistance, since the enforcement officer is vested with state power (and therefore is authorized to use the force, as the police).

In conducting enforcement proceedings, the Belarus legislator set forth many authorizations, which basically match with the authorizations of the majority of modern legal systems, but also, have a broader scope. First, the enforcement officer is authorized to collect money and (or) other property that belongs to the debtor and that is in the possession of debtor and (or) third parties, in the manner prescribed by the law, and to decide to suspend transactions on bank accounts of citizens and legal entities.

In addition to that, the enforcement officer is authorized to prohibit the debtor and other persons to take actions that prevent enforcement related to monetary and (or) other debtor's property, as well as to order these persons to perform certain actions that will help enforcement. For example, the prohibition against enforcement debtor to open new bank accounts in the Belarus banks is often used in practice. This measure is most often used at the same time with the measure of prohibition to dispose of funds owned by the enforcement debtor in the existing bank accounts, with the goal of preventing evasion through opening of other bank accounts. Also, one of the interesting and modern examples in practice is a prohibition to enforcement debtor to use mobile phone and internet services which is implemented by imposing to the operator an order to cancel these services ${ }^{7}$. In other words, these are the prohibitions that may be imposed against the debtor or other persons aimed at preventing obstacles to enforcement.

Furthermore, the public enforcement officer may prohibit the debtor to use his/her own property or may limit the use of such a property, in cases when the use of property may cause a decrease of its value or deterioration, and may prohibit the debtor of enforcement debtor to perform his/her own obligation to the enforcement debtor.

\footnotetext{
${ }^{7}$ Avdeev, A., op. cit., pp. 220-221.
} 
In relation to enforcement on debtor' real property, the enforcement officer is authorized to obtain the information of real property rights, their creation, transfer or termination, as well as of limitation (i.e. burdening) of these rights and to register changes that relate to real property rights registered in favor of enforcement debtor. Also, the immovable property of enforcement debtor and other persons may be used, with the consent of these persons, for keeping the property of the debtor confiscated during enforcement, while the creditor's or debtor' vehicle may be used, if the enforcement officer so decides, for the transport of confiscated property by charging the costs to enforcement debtor. The public enforcement officer may decide on forced traction (evacuation) and storage of confiscated vehicles of the enforcement debtor.

As far as the establishment of relevant facts in the enforcement proceedings is concerned, public enforcement officers are authorized to ask for the participation of interpreters, witnesses, expert witnesses and other persons, as well as specialized organizations that will help in enforcement, which evidently implies the judicial nature of these proceedings. The enforcement officers have the access to the data containing bank and (or) other secrets protected by the law and information that are public notary's confidential information. Finally, they are authorized to receive, free of charge, from citizens, official state authorities and other organizations materials, documents and information necessary for the successful conduct of enforcement.

In addition to that, the modern approach to the enforcement profession in Belarus is evident in the performance of enforcement activities by using information technologies, including electronic document management, official webpages of enforcement agencies in the global computer network, Internet and system of unique calculation and information space. In addition to that in enforcement proceedings enforcement administrations are authorized to use technical devices, including the equipment allowing for sound and video recording, movie and photography.

Finally, the Belarus legislator set forth the right of enforcement officers to a legal remedy against the decisions that are the result of the appeal proceedings related to their decisions or activities (inactivity), and against the decision of the manager of enforcement authority or court decision. We may notice the important authorizations of enforcement officers, not known to the domestic legal system, who may request from the competent authority to review decisions that relate to their own work.

In the above stated context, we shall underline that, although the stated enforcement actions are actually recognized in the domestic system, certain authorizations of the Belarus enforcement officer still imply greater authority 
in actions (for example prohibition to open a new bank account or prohibition to use debtor's own property, use of mobile and internet services). Also, authorizations for sound and video recording of the proceedings is still not included in enforcement activities that may be performed by a public enforcement officer in the Republic of Serbia, and are therefore known only in the court, both civil and criminal proceedings. Finally, electronic communication and conducting certain enforcement activities electronically are part of domestic enforcement proceedings starting from the changes of the law regulating enforcement and security interest that entered into force on January 1, 2020 (for example use of electronic notice board, submitting the motion for enforcement in electronic form, use of data of electronic administration $)^{8}$. Some of these actions are still waiting to be implemented due to the postponed application of certain legal solutions?.

\subsection{The review of the most important duties of enforcement officers}

In addition to the number of authorizations that are entrusted to enforcement officers as state officers in Belarus, there are, on the other side, duties set forth with the goal to set limitations in actions and guarantees that the actions of enforcement officers will not become arbitrariness and direct breach of fundamental procedural and human rights of the participants to the proceedings. ${ }^{10}$

The enforcement officer shall undertake measures of enforcement properly, fully and timely and shall use rights coffered upon him/her in accordance with the law and not to allow the breach of rights and legitimate interests of citizens and legal entities in his/her activities. Also, he/she is also obliged to confirm his/her authority in conducting official duties by presenting official ID and to exclude himself if he/she is directly or indirectly interested for the outcome or if he/she is related to the case through marriage, other close

\footnotetext{
${ }^{8}$ See Art. 36, Art 62a, Art. 171a Zakona o izvršenju i obezbeđenju [Law on Enforcement and Security Interest]. Službeni glasnik RS, br. 106/15, 106/16 - autentično tumačenje, 113/17 autentično tumačenje i 54/19.

${ }^{9}$ Ibid., Art. 168.

${ }^{10}$ Some authors underline not only the legal but also the moral dimension in limitation of debtor's rights in enforcement proceedings and state that actions of enforcement officers although conducted in legal framework may be considered as moral only if introduced with limitations not to breach the right to honor and dignity and dissent life of enforcement debtor. Barsukova, V., N. (2015). Limitations of the debtor rights in enforcement proceedings: Legal and Moral Dimension, The Restriction of the Rights of the Debtor: The Latest Legislative Changes and their Implementation, 6th International Scientific and Practical Conference, 8-10 September 2015, Ulan-Ude, Republic of Buryatia.
} 
relations, property, guardianship or other circumstances that cause suspicion in his/her impartiality.

Furthermore, he/she is obliged to keep the data known to him/her in relation to the conduct of his/her official duties that represent the state, trade, bank and (or) other secret protected by the law, as well as other data whose distribution is limited, as confidential and not to disclose them or to make them available to unauthorized persons. He is obliged to offer a possibility to parties and their representatives to inform themselves about the enforcement proceedings material (except for the document containing information whose distribution and (or) handover is limited) and to make them available the copies of case files at their own expense.

We may see that the duties of enforcement officers are almost the same as the duties of the enforcement officers in the Republic of Serbia. Therefore, they remind of the obligation to protect the principle of legality ${ }^{11}$ by enforcement officers, which has the rank of constitutional principle in the majority of legal systems, followed by the obligation to respect the fundamental human rights of the participants in the proceedings (also a constitutional principle). Furthermore, this principle is supplemented by the obligation of confidentiality as one of the basic standards of professional ethics, since the noncompliance with the ethical codex would lead to endangerment of the reputation of the entire profession and even disciplinary liability of the enforcement officer in certain cases.

In terms of cooperation with other state authorities, the enforcement officer is obliged to enforce orders of other enforcement officers and to undertake certain enforcement actions on the territory for which he/she is appointed. If during the enforcement proceedings he/she notices abuses, misdemeanor or any other breach of the law, he/she shall inform competent authorities thereof and assist competent authorities in the search for the debtors in enforcement proceedings.

Finally, as it was underlined at the beginning of this paper, since the enforcement service in the Republic of Belarus was derived from the judicial function, it was important to assess the role of the court in such an organized

\footnotetext{
${ }^{11}$ Namely, the enforcement officers perform the legally transferred judicial power whose fulfillment depends on the proper application of legal provisions. While conducting his/her duties the enforcement officer is acting in accordance with procedural rules and decides based on substantive law rules. In addition to that, the principle of legality means that the enforcement officers have to comply with the statutory provisions and regulations. Stanković, G., Palačković, D., Trešnjev, A. (2018). Komentar Zakona o izvršenju i obezbeđenju [The Comments to the Law on Enforcement and Security Interest]. Beograd, Službeni glasnik, p. 1397.
} 
enforcement proceeding. Having in mind the broad scope of authorizations of enforcement officers we have mentioned earlier, the role of the court in the Belarus enforcement proceedings is limited to certain issues that are aimed to secure compliance of the enforcement debtor with the enforceable document. Therefore, authorizations that are kept in the competence of the court relate primarily to decisions on limitation of enforcement debtor's movement when the enforcement proceedings so require.

Namely, the court is authorized, in the enforcement proceedings, to temporarily restrict the right of an enforcement debtor, including the entrepreneur as well as an authorized person in a legal entity, to leave the Republic of Belarus $^{12}$ until the obligation which is the subject matter of proceedings is not fulfilled in full. We shall underline that this measure has been very effective in practice, although its application has started only in $2011^{13}$. Furthermore, the court may pass a decision to limit the enforcement debtor the use of motor vehicles, motor vessels, hunting rights, except in cases when the debtors use this right as disabled persons or as the only source of income. The measure of prohibition to drive motor vehicles also showed in practice as very efficient since in certain Belarus regions it brought to the successful completion of $75 \%$ of initiated enforcement proceedings ${ }^{14}$. Finally, this legal system is specific because the court is authorized to temporarily limit the enforcement debtor to visit casinos.

In accordance with the above mentioned, at this point we may notice the application of measures and limitations against the debtors which are not known to the domestic proceedings before public enforcement officers, but are characteristic only to court criminal proceedings.$^{15}$ However, a very important authorization to decide on legal remedies related to enforcement officer's work - decisions on appeals against the decisions and actions

\footnotetext{
${ }^{12}$ This judicial authorization was the subject matter of certain decisions of the European Court of Human Rights. See Case Peltonen versus the Republic of Finland, February, 201995 N 19583/92. Parfenchikova, A. A. (2015). Limitations of the debtor personal rights in terms of international legal standards, The Restriction of the Rights of the Debtor: The Latest Legislative Changes and their Implementation, 6th International Scientific and Practical Conference, 8-10 September 2015, Ulan-Ude, Republic of Buryatia.

${ }^{13}$ For example, in $201447 \%$ of the total number of enforcement proceedings, in which these measures of limitations were imposed, were successfully completed. B. Avdeev, A., op. cit., p. 222.

${ }^{14}$ Ibid.,

${ }^{15}$ Namely, some of these measures may be passed in the criminal proceedings only upon completion of the proceedings, as well as the punishment to the convicted person (for example the prohibition to drive motor vehicle), while others represent measures to secure the presence of convicted person in order to achieve undisturbed criminal proceedings (for example prohibition to leave the place of temporary residence or prohibition to visit certain places).
} 
(inactivity) of enforcement officers is still part of court competence, as in the domestic legal system. In relation to this, we shall mention the standpoints of theory, which even though the participation of enforcement officers changed the nature of enforcement proceedings, they shall still be mostly considered as judicial proceedings, since the actions in these proceedings are undertaken based on the appropriate court decisions. ${ }^{16}$

\section{Enforcement officer's liability}

The enforcement officers in Belarus may have disciplinary, civil (material), administrative and criminal liability.

In terms of criminal liability, the Belarus criminal law does not set forth the special groups of criminal offences that may be committed by enforcement officers in conducting their duties. However, other incriminated offences include certain offences that may be related to the actions of the enforcement officers. These are namely: theft based on abuse of authorizations ${ }^{17}$, abuse of power or official authorizations ${ }^{18}$, inactivity of official person ${ }^{19}$, exceed of authorizations or official authorizations ${ }^{20}$, official forgery ${ }^{21}$, official negligence ${ }^{22}$, and accepting bribes ${ }^{23}$. In case the criminal proceedings are initiated, the enforcement officers may be processed as other public servants.

However, although there is a possibility to perform an action that constitutes certain criminal offence, it may happen that the participants in the proceedings suffer certain damages. Therefore, the issue of civil law liability of enforcement officer for the damages caused to the participants in the proceedings is regulated in the Belarus legal system based on the principle of liability of the legal entity for actions of their bodies. In accordance with the Civil Law of Republic of Belarus (hereinafter the Civil Law) the damages caused to the citizens or legal entity as a result of illegal actions (inactivity) of state authorities, local self-government authorities and self-government or officials of these authorities including issuing of the document which is not

\footnotetext{
${ }^{16}$ Keča, R. (2012). Građansko procesno pravo, Priručnik za polaganje pravosudnog ispita [Civil Procedural Law, Bar Examination Guidelines], Beograd, Službeni glasnik, p. 524

${ }^{17}$ Art. 210 of the Criminal Law of the Republic of Belarus (hereinafter: Criminal Law).

${ }^{18}$ Ibid., Art. 424.

${ }^{19}$ Ibid., Art. 425.

${ }^{20}$ Ibid., Art. 426.

${ }^{21}$ Ibid., Art. 427.

22 Ibid., Art. 428.

${ }^{23}$ Ibid., Art. 430.
} 
in accordance with the law is subject to indemnification. ${ }^{24}$ The damages shall be compensated at the expense of state treasury of the Republic of Belarus or treasury of administrative-territorial unit. The damages include costs suffered by the person whose right was violated or the costs that will be suffered to regain this right, or loss or damages on the property (actual damages) or lost earnings that would be gained by this person in regular circumstances of civil transactions in case his/her right was not violated (lost earnings). ${ }^{25}$

However, the person who compensated the damages caused by the other person (employee in conducting official or other duties) to the damaged person, has the right to request the return of these funds (refund) in the amount of paid compensation. ${ }^{26}$ Therefore the damages caused by the enforcement officer shall be first compensated by the state, which then has the right to ask for the refund from the enforcement officer or other employee who is liable for the damages caused to the citizen or a legal entity. In accordance with the stated legal provisions the principle of objective liability applies here, that means the liability of legal entity (state) regardless of the guilt. ${ }^{27}$

We may see a significant distinction comparing to the solution prescribed in the domestic legal system. Since the public enforcement officers in the Republic of Serbia are non-state entities, and since they perform their duties in the form of entrepreneurship, they are liable with their entire property for the damages caused by their fault ${ }^{28}$. Therefore, we may notice that the liability depends here on the principle of guilt, which is less severe, a subjective principle of liability. The guilt exists when the liable person caused the damages intentionally or negligently ${ }^{29}$ and it is assumed unless the liable person proves to the contrary. However, it is strictly prescribed that the Republic of Serbia is not liable ${ }^{30}$ for this damage, whereby the legislator underlined once more the independence of this judicial profession and its separation from the state power. Apart from this, the public enforcement officer is not liable only for his/her direct actions but also for the damages caused to the participants by his/her deputy or assistant.

\footnotetext{
${ }^{24}$ Ibid., Art. 938.

${ }^{25}$ Ibid., Art. 14.

${ }^{26}$ Ibid., Art. 950.

${ }^{27}$ Radovanov, A. (2009). Obligaciono pravo - opšti deo [Law on Contracts and Torts - general part], Novi Sad, Pravni fakultet za privredu i pravosuđe, p. 247.

${ }^{28}$ Art. 498 paragraph 1 of the Law on Enforcement and Security Interest.

${ }^{29}$ Art. 158 of the Law on Contracts and Torts.

${ }^{30}$ Art. 498 paragraph 2 of the Law on Enforcement and Security Interest.
} 
This is an important novelty comparing to the previous concept when the enforcement proceedings in the Republic of Serbia were in the exclusive competence of the court and there was no direct liability of the judge as the state power executor. In other words, the respondent in the proceedings for the damages caused by the judge in the enforcement proceedings was the Republic of Serbia, which had the right to ask for the refund if the damages caused by the judge were caused intentionally. ${ }^{31}$ Therefore, when the judge and potential damages caused by his/her actions in the enforcement proceedings are concerned, the Serbian and Belarus concept of indemnification does not actually differ.

Finally, a very important issue in the sphere of enforcement officer's liability, which is practically more often present than the issue of his/her criminal and financial liability is the issue of his/her disciplinary liability. This liability does not exclude other types of liability of the members of enforcement profession. Since there is no universal definition of the concept of disciplinary offence, each legal system exhaustively enumerates classification of behaviors of the enforcement officers that are considered a breach of discipline that brings certain punishments.

In relation to the discipline liability of the members of enforcement authorities in Belarus, the most common disciplinary offences are the following: late execution of enforcement actions, breach of law on enforcement proceedings, inadequate implementation of the management's instructions, failure to set performance indicators.

The authorizations in the disciplinary proceedings against the officers of territorial executive bodies are vested in the managers of principal city judicial administrations of regional executive boards (city of Minsk), and for principal enforcement officers in the regions (city of Minsk) are vested in officers of the Principal administration for enforcement - Minister of Justice of the Belarus Republic. Therefore, we may see that higher instance authority that participated in the appointment of the members of lower instance enforcement authority is also in charge of conducting disciplinary proceedings and choice of disciplinary sanctions.

The right of choice of disciplinary sanction belongs to the manager of the competent state body. While choosing the disciplinary measure the following shall be taken in consideration: the severity of the disciplinary offense, circumstances under which it was committed, previous service and behavior

\footnotetext{
${ }^{31}$ Art. 6 paragraph 2 of the Law on Judges. This concept may apply today for part of the enforcement proceedings that is implemented before the court.
} 
of the officer in public service. Therefore, the following disciplinary measures may be imposed against public officers for nonperformance or inproper conduct of official duties: objection, reprimand, warning on incomplete official response, decrease in the class of state officers up to six months and the most severe - discharge from the duty, whereas the objection and reprimand are the two less severe and most often imposed measures. For each disciplinary offence only one disciplinary measure may be imposed, and the decision on disciplinary measure may be appealed before the court.

In the Republic of Serbia, also, the disciplinary liability takes an important place in effective enforcement procedural law, while disciplinary breaches may be less and more severe and are exhaustively listed in the effective law. However, since there is no hierarchy in the organization of public enforcement profession, the unique disciplinary commission is in charge for conducting disciplinary proceedings and passing the decision on disciplinary liability, which consists of the members proposed by the competent ministry and Chamber of public enforcement officers. The disciplinary measures that may be imposed are similar in severity and content to the measures of Belarus system, but there is a possibility of fine against the public enforcement officer in the domestic legislature. ${ }^{32}$ Therefore, there is an evident procedural distinction in conducting disciplinary proceedings between these two legal systems, but in financial terms, the basis and consequences of the liability are mostly matching.

\section{Conclusion}

After considering the effective provisions of the Belarus enforcement law, we may conclude that the main characteristic of the status of Belarus enforcement officers is that they act as the representatives of state power, i.e., they have official authorizations in conducting their professional duties. At the same time, it is the principle distinction comparing to the domestic concept in which the public enforcement officer is a non-state entity that conducts the duties as an entrepreneur. As a consequence, to this, certain authorizations of the enforcement officers in Belarus system are the most adequate illustration of state structure of this service and broad scope of authorizations against the enforcement debtor.

\footnotetext{
${ }^{32}$ Less severe disciplinary measures include warning and fine, while more severe measures include public warning, fine, temporary prohibition to conduct service, as well as permanent prohibition to conduct service, see Art. 528 of the Law on Enforcement and Security Interest.
} 
In the above mentioned context, we shall underline that, although the actions of enforcement in the Belarus system are in its merits recognized also in the domestic law, certain authorizations of the Belarus enforcement officer are still more autorotative (for example application of force) and reflect the state structure of this service. Also, certain authorizations of the Belarus enforcement officer are recognized in the domestic law only as part of court authorizations in the court, primarily criminal proceedings. Finally, electronic communication and conducting certain enforcement actions electronically in Belarus are part of domestic enforcement proceedings starting from the date when the changes to the Law on Enforcement and Security Interest entered into force this year.

Finally, a very important difference comparing to the system prescribed by the domestic legal system is civil liability of enforcement officers, i.e., application of objective liability of the Republic of Belarus for the damages caused to the participants in the proceedings by the enforcement officer, since the public enforcement officers in the Republic of Serbia are non-state entities who are liable with their entire property for the damages caused by their fault.

\section{Masnikosa Vujadin}

Dr, zamenik predsednika Komore javnih izvršitelja Srbije

\section{POLOŽAJ I OVLAŠĆENJA IZVRŠITELJA U PRAVNOM SISTEMU BELORUSIJE}

REZIME: S obzirom na to da profesija izvršitelja ima sve efikasniju ulogu kako u obezbeđenju tako i u realizaciji potraživanja poverioca, čemu je u značajnoj meri doprinelo uvođenje sistema izvršitelja kao samostalnih, nedržavnih subjekata u velikom broju pravnih sistema (tzv. vansudski izvršitelji), autor u ovom radu analizira beloruski model prema kome je profesija izvršitelja i dalje deo aparata državne vlasti, te njegova osnovna obeležja. Na pojedinim mestima, autor će izvršiti poređenje sa aktuelnim položajem javnih izvršitelja u Republici Srbiji, te izneti zaključak o efikasnosti oba modela.

Ključne reči: izvršenje, uprava prinudnog izvršenja, izvršitelj, pristav, ovlašćenje, dužnost 


\section{References}

1. Avdeev, A. (2015). The sufficiency of the restriction measures against debtors in the process of enforcement proceedings, The Restriction of the Rights of the Debtor: The Latest Legislative Changes and their Implementation, 6th International Scientific and Practical Conference, 8-10 September 2015, Ulan-Ude, Republic of Buryatia

2. Barsukova, V. N. (2015). Limitations of the debtor rights in enforcement proceedings: Legal and Moral Dimension, The Restriction of the Rights of the Debtor: The Latest Legislative Changes and their Implementation, 6th International Scientific and Practical Conference, 8-10 September 2015, Ulan-Ude, Republic of Buryatia

3. Bodiroga, N. (2017). Novi izvršni postupak [New Enforcement Proceedings], Beograd, Pravni fakultet Univerziteta u Beogradu

4. Keča, R. (2012). Građansko procesno pravo, Priručnik za polaganje pravosudnog ispita [Civil Procedural Law, Bar Examination Guidelines], Beograd, Službeni glasnik

5. Parfenchikova, A. A. (2015). Limitations of the debtor personal rights in terms of international legal standards, The Restriction of the Rights of the Debtor: The Latest Legislative Changes and their Implementation, 6th International Scientific and Practical Conference, 8-10 September 2015, Ulan-Ude, Republic of Buryatia

6. Radovanov, A. (2009) Obligaciono pravo - opšti deo [Law on Contracts and Torts - general part], Novi Sad, Pravni fakultet za privredu i pravosuđe

7. Selaković, N. (2007) Dušanov zakonik i pravni transplanti [Dusan's Law and Legal Transplants], Beograd, Pravni fakultet Univerziteta u Beogradu.

8. Stanković, G., Palačković, D., Trešnjev, A. (2018). Komentar Zakona o izvršenju i obezbeđenju [The Comments to the Law on Enforcement and Security Interest], Beograd, Službeni glasnik

9. Civil Code of Republic of Belarus dated December 7, 1998 no. 218-Z, as amended on Decembar 28, 2009.

10. Criminal Code of the Republic of Belarus dated July 9, 1999, no. 275-Z, as amended on 11-11-2019.

11. Law of the Republic of Belarus dated October 24, 2016 no. 439-Z „On the Enforcement Proceedings“, as amended on 18-12-2019.

12. Zakon o izvršenju i obezbeđenju [Law on Enforcement and Security Interest], Službeni glasnik RS, br. 106/15, br. 106/16 - autentično tumačenje, 113/17 - autentično tumačenje 54/19. 
13. Zakon o obligacionim odnosima [Law on Contracts and Torts], Službeni list SFRJ, br. 29/78, 39/85, 45/89 - odluka USJ i 57/89, Službeni list SRJ, br. 31/93, Službeni list SCG, br. 1/03 - Ustavna povelja i Službeni glasnik $R S$, br. $18 / 20$

14. Zakon o sudijama [Law on Judges], Službeni glasnik $R S$, br. 116/08, 58/09 - odluka US, 104/09, 101/10, 8/12 - odluka US, 121/12, 124/12 odluka US, 101/13, 111/14 - odluka US, 117/14, 40/15, 63/15 - odluka US, 106/15, 63/16 - odluka US i 47/17 